\title{
o3. Öge Gösterim Kuramına dayalı kavram öğretiminin ortaokul 7. sınıf öğrencilerinin Türkçe dersindeki başarılarına etkisi
}

Taha Yasir CEVHER²

\section{Suat UNGAN3}

\begin{abstract}
APA: Cevher, T. Y.; Ungan, S. (2021). Öge Gösterim Kuramına dayalı kavram öğretiminin ortaokul 7. sınıf öğrencilerinin Türkçe dersindeki başarılarına etkisi. RumeliDE Dil ve Edebiyat Araşturmalar Dergisi, (23), 30-48. DOI: 10.29000/rumelide.948286.
\end{abstract}

\section{$\ddot{O} \mathbf{z}$}

$\mathrm{Bu}$ araştırmanın amacı Öge Gösterim Kuramına dayalı kavram öğretiminin ortaokul 7. sınıf öğrencilerinin Türkçe dersindeki başarılarına etkisini inceleyerek bu kurama yönelik öğrenci görüşlerini belirlemektir. $\mathrm{Bu}$ amaç doğrultusunda araştırmada nicel ve nitel araştırma yöntemlerinin birlikte kullanıldı ̆̆ karma araştırma yöntemlerinden gömülü desen kullanılmıştır. Araştırmanın çalışma grubunu Trabzon ili Yomra ilçesinde bulunan bir ortaokulun 2 farklı şubesinde öğrenim gören 45 7. sınıf öğrencisi oluşturmaktadır. Sınıflardan biri deney, diğeri kontrol grubu olarak belirlenmiştir. Araştırmada veri toplama aracı olarak kavram başarı testi ve yarı yapılandırılmış görüşme formu kullanılmıştır. Veri toplama araçlarından kavram başarı testi her iki gruba da ön test olarak uygulanmıştır. 6 hafta süren uygulama sürecinde deney grubunda dersler Öge Gösterim Kuramı ile işlenirken kontrol grubunda programa dayalı öğretim süreci devam etmiştir. Uygulama sürecinin ardından her iki gruba kavram başarı testi uygulanarak araştırmanın nicel veri toplama süreci sona ermiştir. Araştırmanın nitel verileri ise deney grubu ile yapılan yarı yapılandırılmış görüşme formu ile toplanmıştır. Araştırma sonucunda kavram başarı testinden elde edilen verilerin analizinde bağımsız gruplar t testi, eşleştirilmiş gruplar t testi, yarı yapılandırılmış görüşme formunun analizinde ise içerik analizi kullanılmıştır. Araştırma sonucunda Öge Gösterim Kuramına dayalı kavram öğretiminin öğrencilerin başarıları üzerinde olumlu etkiye sahip olduğu ve öğrencilerin bu kuramın kullanımına yönelik görüşlerinin olumlu yönde olduğu tespit edilmiştir.

Anahtar kelimeler: Öge gösterim kuramı, kavram öğretimi, Türkçe öğretimi

\section{The effect of concept teaching based on component display theory on 7 th grade students' achievements in Turkish lesson}

\begin{abstract}
The aim of this research is to investigate the effect of concept teaching with Component Display Theory (CDT) on middle school seventh-grade students' academic achievements in Turkish lesson and to explore students' views on this theory. To this end, the study used a mixed methods research design which combines quantitative and qualitative research methods. The sample consisted of 45 seventh-grade students attending two separate sections of a middle school located in the Yomra
\end{abstract}

Bu makale Prof. Dr. Suat UNGAN’ın danışmanlığında Taha Yasir Cevher’in Trabzon Üniversitesi Lisansüstü Eğitim Enstitüsü’nde hazırladı̆̆ı aynı başlıklı doktora tezinden üretilmiştir.

Arş. Gör. Dr., Hakkari Üniversitesi, Eğitim Fakültesi, Türkçe ve Sosyal Bilgiler Eğitimi Bölümü, Türkçe Eğitimi ABD (Hakkari, Türkiye), tahayasircevher@gmail.com, ORCID ID: 0ooo-0oo3-2437-2354 [Araştırma makalesi, Makale kayıt tarihi: 29.03.2021-kabul tarihi: 20.06.2021; DOI: 10.29000/rumelide.948286]

Prof. Dr., Trabzon Üniversitesi, Eğitim Fakültesi, Türkçe ve Sosyal Bilgiler Eğitimi Bölümü, Türkçe Eğitimi ABD (Trabzon, Türkiye), ummagan@gmail.com, ORCID ID: oooo-0003-4020-6655

Adres | Address

RumeliDE Dil ve Edebiyat Araştırmaları Dergisi $\quad$ RumeliDE Journal of Language and Literature Studies Osmanağa Mahallesi, Mürver Çiçeği Sokak, No:14/8 $\quad$ Osmanağa Mahallesi, Mürver Çiçeği Sokak, No:14/8

Kadıköy - İSTANBUL / TÜRKIYE 34714 Kadıköy - ISTANBUL / TURKEY 34714 e-posta: editor@rumelide.com

e-mail: editor@rumelide.com

tel: +90 505 7958124, +90 216773 o 616 phone: +90 505 7958124, +90 2167730616 


\begin{abstract}
District of Trabzon. One section was treated as the experimental group and the other as the control group. The data were collected using a concept achievement test and a semi-structured interview form. The concept achievement test was administered to both groups as a pretest. During the sixweek experimental procedure, lessons were taught using CDT in the experimental group and curriculum-based instruction in the control group. After the experimental procedure, the concept achievement test was re-administered to both groups. Thus, the process of quantitative data collection was ended. The qualitative data were collected through semi-structured interviews held with the experimental group. The quantitative data from the achievement test were analysed using an independent samples t-test and a paired-samples t-test and the qualitative data from the interviews were analysed through content analysis. The analysis results showed that concept teaching with CDT has a positive effect on students' achievement and the students have positive views on the use of CDT in concept teaching.
\end{abstract}

Keywords: Component display theory, concept teaching, Turkish teaching

\title{
1. Giriş
}

İnsanoğlunun dünyaya gelişi ile başlayan kavram öğrenimi, ölünceye kadar devam eder. Kavramlar yaş, tecrübe, sosyoekonomik durumlar ve eğitim geçmişi gibi sebeplere bağlı olarak düşünce dünyasında anlamlar oluşturur. Yaş ilerledikçe, bilgi ve deneyim arttıkça daha karmaşık kavramlar öğrenilir. Yeni öğrenilen her kavram, öğrenilmiş olan kavramlarla ilişkilendirilerek anlamlı hâle gelir. Zamanla öğrenilen bu kavramların bir kısmı zihnimizde kalıcı bir şekilde yer bulurken, bir kısmı da unutulur.

Bilgi çă̆ı şeklinde adlandırılan 21. yüzyılda; bilgiye erişmek, onu kullanmak ve üretmek tüm toplumların ortak hedefleri arasındadır. Bilgiyi hayatının olmazsa olmazı şeklinde düşünen toplumlar, yeryüzünde olup biten her şeyden haberdar olmak istemekte ve diğer toplumlarla etkileşime girmektedir. Bilginin bu denli önemli olması ve eğitim, kültür, sanat vb. birçok boyutta insan yaşamına etki etmesi, bilgi toplumunun oluşturulmasını ve geliştirilmesini sağlamaktadır.

Bilgi toplumu, bilginin üretim için temel bir kaynak olduğu, bilginin üretimi ve iletiminin yaygınlaştığı, sürekli öğrenme ve bilgilenme yoluyla değişim ve gelişimin kaçınılmaz hâle geldiği yeni bir dönemi ifade etmektedir (Öğüt, 2003). Sanayi devriminden sonra insanlı̆̆ etkileyen en önemli olay olarak nitelendirilen bilgi toplumunun, ekonomik, siyasal, toplumsal ve kültürel alanlarda köklü değişiklere yol açtı̆̆ görülmektedir (Kaplan, 1991). Bu dönemin etkileri her alanda olduğu gibi eğitim alanında da kendini göstermiş, devletler eğitim sistemleri üzerinde kapsamlı değişikliklere gitmiş, birçok yeniliklere imza atmıştır. Bu yenilikler; eğitim reformları, modern eğitim kurumları oluşturma çabaları, modern öğretim araç ve gereçlerinin sağlanması, öğretmenlerin mesleki bilgi ve beceri düzeylerinin artırılmasını, öğretme-öğrenme sürecini geliştirmeye yönelik uygulamaları kapsamaktadır (Karip ve Köksal, 1996).

Yeni eğitim teknolojilerinin ve uygulamalarının gelişmesini sağlayarak öğrenmeyi herkes için olanaklı bir duruma getiren bilgi çağında (Kaplan, 1991), elde edilen bilgi birikiminin bütünüyle öğrenenlere aktarılması mümkün olamayacağı için, son yıllarda artık kavramlar düzeyinde öğretime önem verilmeye başlanmıştır (Özmen, 2005). Eğitim çoğunlukla kavramlarla ilgilidir. Kavramlar, tanımlama ve adlandırma özelliklerine sahip olmaları sebebiyle öğrenmenin en önemli unsurlarından biridir. Bu öğretimle uyaranları belli kategorilere ayırarak zihinde bilgiler oluşturulması sağlanmaktadır. Bilginin

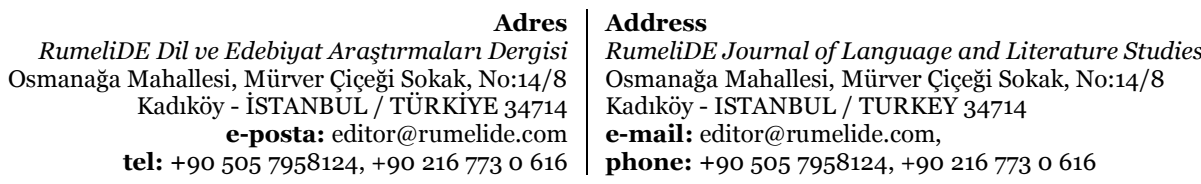


The effect of concept teaching based on component display theory on 7th grade students' achievements in Turkish lesson / T. Y. Cevher; S. Ungan (pp. 30-48)

oluşturulması sürecinde gelişigüzel veya ezbere öğrenmeden ziyade bireyi merkeze alan bir yaklaşımla, bireyin doğrudan katılımını sağlayan keşif yapma ve etkileşimde olma gibi boyutlar da önem kazanmaktadır.

İnsanın kendisini ve çevresindeki olayları anlamaya çalışırken kurduğu düşünce dünyası, kavramlar ve kavramlar arasındaki ilişkilerle biçimlenir. İnsan, kavramların bir dil bütünlüğü içinde kazandıkları değerlerle birlikte sosyalleşir ve dil yardımıyla öğrenme, öğrendiklerini uygulama, yorumlama gibi birtakım düşünme ve ifade etme faaliyetlerinde bulunur (MEB, 2006). Türkçe Dersi Öğretim Programı'nda da gerek temel dil becerilerinin (dinleme, konuşma, okuma, yazma) öğretimi gerekse dil bilgisi öğretimi bağlamında kavram öğretimi önemlidir. Özellikle ana dili öğrenimi sürecinde birey, sahip olduğu kavramlarla dil becerilerini etkin bir şekilde kullanır.

Araştırmanın amacı, öğrenme kuramlarından biri olan Öge Gösterim Kuramı (Component Display Theory) temel alınarak yapılan kavram öğretiminin ortaokul 7. sınıf öğrencilerinin akademik başarıları üzerine etkisini inceleyerek bu konudaki öğrenci görüşlerini belirlemektir.

$\mathrm{Bu}$ amaç doğrultusunda "Öge Gösterim Kuramına dayalı kavram öğretiminin ortaokul 7. sınıf öğrencilerinin Türkçe dersindeki başarılarına etkisi nedir?” problem cümlesi kapsamında aşağıdaki alt problemlere cevap aranmıştır:

1. Öge Gösterim Kuramına dayalı yapılan kavram öğretiminin uygulandığı deney grubu ile programa dayalı öğretimin uygulandığı kontrol grubu arasında başarı açısından anlamlı farklılık var mıdır?

2. Öge Gösterim Kuramına dayalı yapılan kavram öğretimi öğrencilerin başarıları üzerinde ne düzeyde etkilidir?

3. Öge Gösterim Kuramına dayalı yapılan kavram öğretiminde deney grubu öğrencilerinin başarı puanları cinsiyete göre farklıllk göstermekte midir?

4. Deney grubu öğrencilerinin Öge Gösterim Kuramına dayalı yapılan kavram öğretimine yönelik görüşleri nelerdir?

\section{Yöntem}

\section{1. Araştırma modeli}

Öge Gösterim Kuramına dayalı kavram öğretiminin ortaokul 7. sınıf öğrencilerinin Türkçe dersindeki başarılarına etkisini incelemeyi amaçlayan bu çalışmada nicel ve nitel yöntemler bir arada kullanıldığı için karma yöntem yaklaşımı benimsenmiştir. Karma araştırma, araştırmacının araştırma problemlerini anlamak için toplamış olduğu iki veri setini (nitel, nicel) bütünleştirmenin avantajlarını kullanarak sonuçlar çıkardığı, sağlık, sosyal ve davranış bilimleri alanında kullanılan bir araştırma yöntemidir (Creswell, 2017). Araştırmanın amacı göz önünde bulundurulduğunda karma yöntem kullanılmasının sebebi yeni bir öğretim yaklaşımı ile tanışan öğrencilerin başarı durumları, görüşleri ve hisleri gibi durumların incelenmesidir. Araştırmada nicel verilerin yanı sıra nitel verilerin kullanılmasının sebebi nicel verileri desteklemenin yanı sıra öğrencilerin farklı durum ve bakış açlarını ortaya koymaktır.

\begin{tabular}{r|l} 
Adres & Address \\
RumeliDE Dil ve Edebiyat Araşțrmaları Dergisi & RumeliDE Journal of Language and Literature Studies \\
Osmanağa Mahallesi, Mürver Çiçeği Sokak, No:14/8 & Osmanağa Mahallesi, Mürver Çiçeği Sokak, No:14/8 \\
Kadıöy - İSTANBUL / TÜRKIYY 34714 & Kadıköy - ISTANBUL / TURKEY 34714 \\
e-posta: editor@rumelide.com & e-mail: editor@rumelide.com, \\
tel: +90 505 7958124, +90 216773 o 616 & phone: +90 505 7958124, +90 216773 o 616
\end{tabular}


$\mathrm{Bu}$ araştırmada nicel bir araştırmaya nitel verilerin destekleyici olarak dâhil edilmesi söz konusudur. $\mathrm{Bu}$ doğrultuda araştırmanın deseni karma gömülü desen olarak belirlenmiştir. Gömülü desen, nitel veya nicel veriden herhangi birisinin diğerini desteklemesi için kullanıldığı karma yöntem tasarımıdır. $\mathrm{Bu}$ tasarım, tek bir veri setinin yeterli olmadığı, farklı soruların cevaplanması gerektiği ve her soru türünün farklı türde veri gerektirdiği durumlarda kullanılır. Bu desen büyük ölçüde nicel olan bir çalışmaya nitel verilerin veya büyük ölçüde nitel olan bir çalışmaya nicel verilerin destekleyici olarak dâhil edilmesi gerektiğinde kullanılır (Cresweel ve Plano-Clark, 2007). Bu çalışmada ağırlıklı olarak nicel verileri desteklemek için nitel veriler kullanılmıştır.

Karma araştırma yöntemlerinden gömülü desene yönelik tasarlanmış olan bu çalışmanın nicel boyutunda, nicel araştırma yöntemlerinden ön test- son test kontrol gruplu yarı deneysel desen kullanılmıştır. "Deneysel araştırmalar, araştırmacı tarafından oluşturulan farkların bağımlı değişken üzerindeki etkisini test etmeye yönelik çalışmalardır. Deneysel desenlerde temel amaç değişkenler arasında oluşturulan neden sonuç ilişkisini test etmektir" (Büyüköztürk, Çakmak, Akgün, Karadeniz ve Demirel, 2016, s. 195). Araştırmada kullanılan deneysel desenin simgesel görünümü Tablo 1'de verilmiştir.

Tablo 1. Ön test son test kontrol gruplu deneysel desen

\begin{tabular}{llll} 
Grup & Ön Test & İşlem & Son Test \\
\hline DG & $O_{1}$ & $\mathrm{X}$ & $O_{3}$ \\
KG & $O_{2}$ & & $O_{4}$
\end{tabular}

Araştırmanın nitel boyutunda ise, nicel verileri desteklemek amacıyla deney grubunda yer alan öğrencilerle yarı yapılandırılmış görüşme yapılmıştır.

\section{2. Araştırma grubu}

Bu araştırma 2018-2019 eğitim öğretim yllında Trabzon ili Yomra ilçesinde bulunan bir ortaokulun iki farklı şubesinde öğrenim gören toplam 45 yedinci sınıf öğrencisi ile yürütülmüştür. Sınıflardan birisi Öge Gösterim Kuramına yönelik hazırlanmış ders planının kullanıldığı deney grubu ( $n=22)$, diğeri ise programa dayalı öğretim yöntemine devam eden kontrol grubu $(n=23)$ olarak yansız atama yoluyla belirlenmiştir. Araştırmanın çalışma grubuna ilişkin demografik bilgiler Tablo 2'de sunulmuştur.

Tablo 2. Çalışma grubuna ilişkin demografik bilgiler

\begin{tabular}{llll}
\hline Gruplar & Cinsiyet & Frekans & Yüzde (\%) \\
\hline \multirow{2}{*}{ DG } & Klz & 10 & 22,3 \\
\cline { 2 - 4 } & Erkek & 12 & 26,7 \\
\hline \multirow{2}{*}{ KG } & Kiz & 12 & 26,7 \\
\cline { 2 - 4 } & Erkek & 11 & 24,3 \\
\hline \multirow{2}{*}{ Toplam } & & 45 & 100 \\
\hline
\end{tabular}

Araştırmanın nitel boyutunun çalışma grubunu ise deney grubu öğrencileri oluşturmaktadır. Seçilen 10 öğrenci ile yarı yapılandırılmış görüşme yapılmıştır. Görüşme yapılacak öğrencilerin seçiminde amaçsal örnekleme yöntemlerinden maksimum çeşitlilik örnekleme yöntemi kullanılmıştır. "Maksimum çeşitlilik örnekleme; evrende incelenen problemle ilgili olarak kendi içinde benzeşik farklı durumların belirlenerek çalışmanın bu durumlar üzerinde yapılmasıdır” (Büyüköztürk vd., 2016, s.

\footnotetext{
\begin{tabular}{r|l} 
Adres & Address \\
RumeliDE Dil ve Edebiyat Araşttrmalar Dergisi & RumeliDE Journal of Language and Literature Studies
\end{tabular} Osmanağa Mahallesi, Mürver Çiçeği Sokak, No:14/8 Osmanağa Mahallesi, Mürver Çiçeği Sokak, No:14/8 Kadıköy - İSTANBUL / TÜRKIYE 34714 Kadıköy - ISTANBUL / TURKEY 34714 e-posta: editor@rumelide.com e-mail: editor@rumelide.com, tel: +90 505 7958124, +90 2167730616 phone: +90 505 7958124, +90 2167730616
} 
The effect of concept teaching based on component display theory on 7th grade students' achievements in Turkish lesson / T. Y. Cevher; S. Ungan (pp. 30-48)

90). Görüşme yapmak için seçilen öğrencilerin cinsiyetleri, başarı durumları (yüksek, orta, düşük) dikkate alınarak çeşitlilik sağlanmıştır.

\section{3. Veri toplama araçları}

$\mathrm{Bu}$ araştırmada veri toplama aracı olarak; araştırmanın nicel boyutunda Öge Gösterim Kuramına dayalı kavram öğretiminin ortaokul 7. sınıf öğrencilerinin Türkçe dersindeki başarılarına etkisini belirlemek amacıyla Kavram Başar Testi, araştırmanın nitel boyutunda ise uygulanan kuramın öğrenci görüşleri açısından değerlendirilmesi amacıyla Yarı Yapılandırılmış Görüşme Formu kullanılmıştır.

\section{3. 1. Kavram başarı testi}

Araştırmada, Öge Gösterim Kuramına dayalı kavram öğretiminin ortaokul 7. sinıf öğrencilerinin Türkçe dersindeki başarılarına etkisini belirlemek amacıyla araştırmacı tarafından "Kavram Başarı Testi" hazırlanmıştır. Kavram başarı testi hazırlanırken öncelikle 7. sınıf Türkçe Dersi Öğretim Programı ve ylllı plan incelenerek uygulamanın yapılacağı zaman zarfında işlenecek konular ve Türkçe öğretmenlerinin görüşü doğrultusunda kavramlar belirlenerek soru havuzu oluşturulmuştur.

Hazırlanan çoktan seçmeli soruların ölçülmek istenen bilgi ve becerileri ne kadar ölçtüğünü ve ölçme değerlendirme ilkelerine uygunluğunu belirlemek amacıyla hazırlanan sorular Türkçe Eğitimi alanında uzman üç öğretim üyesinin ve farklı okullarda görev yapan iki Türkçe öğretmeninin görüşüne sunulmuştur. Alınan uzman görüşleri doğrultusunda yapılan gerekli düzeltmelerin ardından toplam 35 maddeden oluşan çoktan seçmeli kavram başarı testi hazırlanmıştır. Hazırlanan test, pilot uygulama için daha önce bu konunun anlatılmış olduğu 8. sınıfta öğrenim gören 120 ortaokul öğrencisine uygulanmıştır. Pilot uygulamadan elde edilen verilerin TestAn - Test ve Madde Analizi Programı'nda madde analizi yapılmıştır. Yapılan madde analizi sonucunda testte yer alan her bir maddeye ait madde güçlük ve madde ayırt edicilik indeksleri hesaplanmıştır.

Yapılan madde analizi sonucunda, testte yer alan maddelerden madde ayırt edicilik indeksi 0.30 ve üzerinde olan maddeler teste dâhil edilmiş 0.30 altında değer alan maddeler $(1,2,9,14,15,16,18$, 22 , 30, 34) testten çıkarılmıştır. Kavram başarı testinde yer alan 25 maddenin ortalama güçlüğü 0.55 , madde ayırt ediciliği ise 0,51 olarak hesaplanmıştır. Testin madde analizi hesaplandıktan sonra testin ne derece güvenilir olduğunu belirlemek için KR-20 katsayısı hesaplanmış ve .81 olarak bulunmuştur.

\section{3. 2. Yarı yapılandırılmış görüşme formu}

Görüşme, özellikle belirli araştırma türleri için bilgi toplarken verilerin belirli varsayımlara dayandırılmasında etkili bir yöntemdir. Özellikle araştırmacılar, katılımcıların bakış açılarını anlamak ya da katılımcıların olgu ve olaylara nasıl anlamlar yüklediklerini öğrenmek istediklerinde, görüşme yapmak etkili bir yöntem olmaktadır (Berg ve Lune, 2015: 139). Görüşmenin yapılandırılmış, yarı yapılandırılmış, yapılandııılmamış ve odak grup görüşme teknikleri vardır. Yarı yapılandırılmış görüşme önceden belirlenmiş bir dizi soruların sorulmasını ve özel bazı konulara değinilmesini içermektedir. Bu sorular genellikle her katılımcıya sistematik ve tutarlı bir sırada sorulur (Berg ve Lune, 2015: 136).

$\mathrm{Bu}$ araştırmada, nicel verileri desteklemek ve Öge Gösterim Kuramının kullanımına yönelik öğrenci görüşlerini almak amacıyla yarı yapılandırılmış görüşme formu kullanılmıştır. Form hazırlanırken

\begin{tabular}{|c|c|}
\hline Adres & Address \\
\hline RumeliDE Dil ve Edebiyat Araşturmaları Dergisi & RumeliDE Journal of Language and Literature Studies \\
\hline Osmanağa Mahallesi, Mürver Çiçeği Sokak, No:14/8 & Osmanağa Mahallesi, Mürver Çiçeği Sokak, No:14/8 \\
\hline $\begin{array}{r}\text { Kadıköy - ÍSTANBUL / TÜRKIYE } 34714 \\
\text { e-posta: editor@rumelide.com } \\
\text { tel: +90 505 7958124, +90 } 2167730616\end{array}$ & $\begin{array}{l}\text { Kadıköy - ISTANBUL / TURKEY } 34714 \\
\text { e-mail: editor@rumelide.com, } \\
\text { phone: +90 505 7958124, +90 } 216773 \text { o } 616\end{array}$ \\
\hline
\end{tabular}


literatürden yararlanılmış taslak sorular hazırlanarak uzman görüşüne sunulmuştur. Türkçe Eğitimi alanında uzman üç öğretim üyesinin ve farklı okullarda görev yapan iki Türkçe öğretmeninin görüşünden gelen düzeltmeler yapılarak görüşme formuna son şekli verilmiştir. Görüşmeler Öge Gösterim Kuramı ile uygulama sürecine katılan deney grubu öğrencileri ile yapılmıştır.

\section{3. 3. Öğretmen kılavuzu ve uygulama sürecinin tasarlanması}

Araştırmanın uygulama süreci ve öğretmen kılavuz kitabı ADDIE tasarım modeline göre hazırlanmıştır. ADDIE modeli; Çözümleme (Analysis), Tasarımlama (Design), Geliştirme (Development), Uygulama (Implementation) ve Değerlendirme (Evaluation) aşamalarından oluşmaktadır (Şimşek, 2017). ADDIE modelinin şematik modeli Şekil 1'de sunulmuştur.

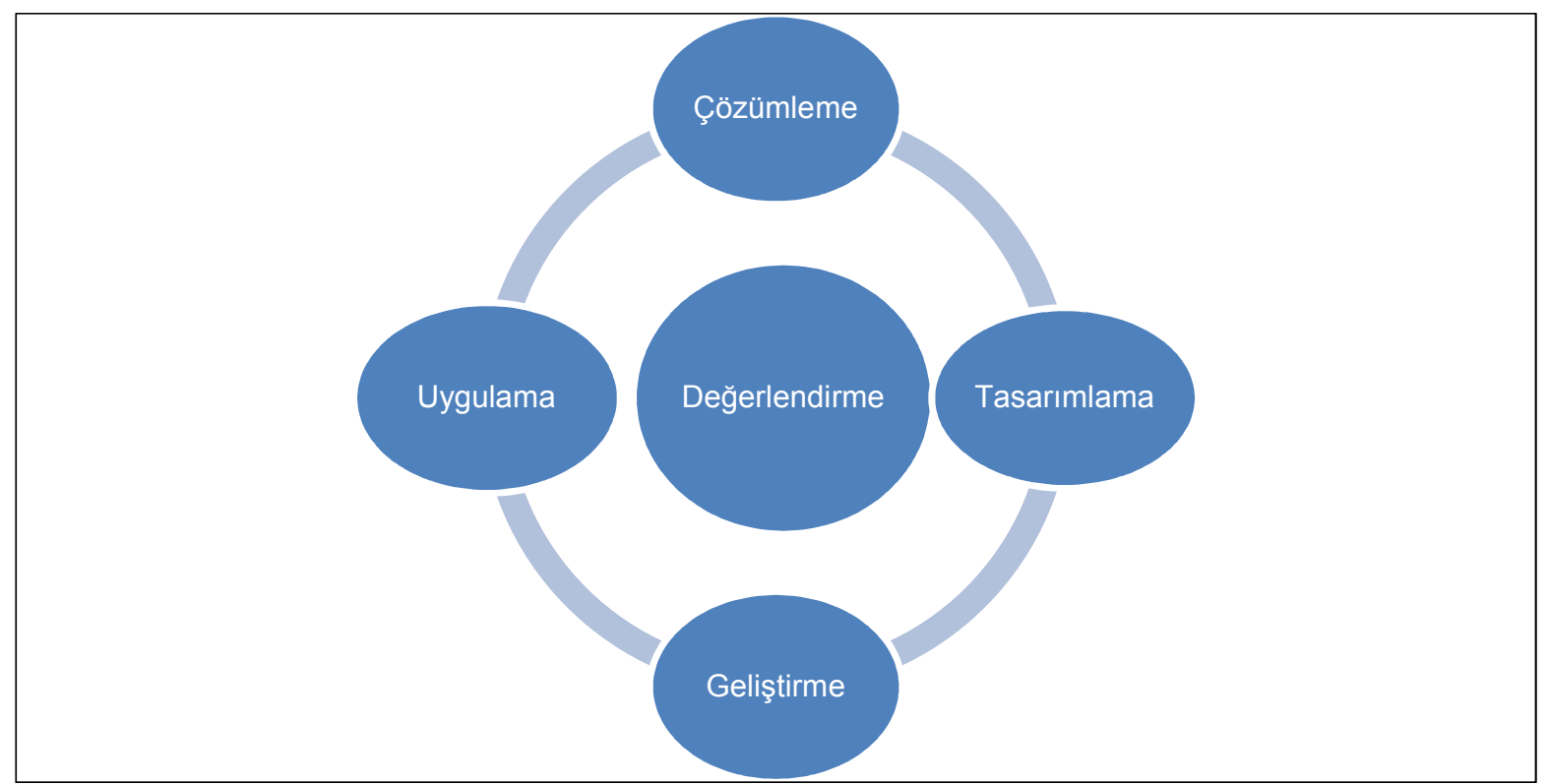

Şekil 1. ADDIE tasarım modeli

Çözümleme (Analysis): Çözümleme aşamasında ilk olarak Öge Gösterim Kuramı ile ilgili literatür taraması yapılmıştır. Yapılan tarama sonucunda kuramın ne olduğu ve nasıl uygulandığı hakkında bilgi edinilerek uygulamanın hangi kavramlar üzerine ve hangi sınıf düzeyinde yapılacağını belirlemek amacıyla müfredat programı incelenmiştir. Belirlenen kavramlar uzman görüşüne sunulmuş ve 7. sınıf öğrencileri ile dil bilgisi kavramlarının Öge Gösterim Kuramı ile öğretimine karar verilmiştir.

Tasarımlama (Design): Tasarımlama aşamasında, bir önceki aşamada belirlenmiş olan 7. sınıf müfredatında yer alan dil bilgisi kavramlarının Öge Gösterim Kuramı ile öğretimine yönelik etkinlikler (kavram haritası, yapılandırılmış grid, anlam çözümleme tablosu, tanılayıcı dallanmış ağaç, zihin haritası) geliştirilmiştir. Tasarlanan etkinlikler uzman görüşüne sunulmuş ve alınan dönütler doğrultusunda etkinlikler düzenlenmiştir.

Geliştirme (Development): Öge Gösterim Kuramı ile öğretilmesi düşünülen kavramlara ve bu kavramların öğretimine yönelik etkinliklerin tasarlanmasından sonra bu etkinliklerin geliştirilmesi aşamasına geçilmiştir. İlgili kavramların öğretimi için kavram öğretim tekniklerinden kavram haritası, yapılandırılmış grid, anlam çözümleme tablosu, tanılayıcı dallanmış ağaç, zihin haritası, otobiyografi gibi farklı etkinlikler geliştirilmiştir. Bu etkinlikler öğrenme sürecinde gerekli yerlerde kullanılmıştır.

Adres $\mid$ Address

RumeliDE Dil ve Edebiyat Araştırmaları Dergisi $\quad$ RumeliDE Journal of Language and Literature Studies Osmanağa Mahallesi, Mürver Çiçeği Sokak, No:14/8 Osmanağa Mahallesi, Mürver Çiçeği Sokak, No:14/8

Kadıköy - ISTANBUL / TÜRKIYE 34714 Kadıköy - ISTANBUL / TURKEY 34714 e-posta: editor@rumelide.com e-mail: editor@rumelide.com

tel: +90 505 7958124, +90 2167730616 phone: +90 505 7958124, +90 2167730616 
The effect of concept teaching based on component display theory on 7th grade students' achievements in Turkish lesson / T. Y. Cevher; S. Ungan (pp. 30-48)

Çalışmada geliştirilen ve ADDIE tasarım modeline göre hazırlanan öğretmen kılavuz kitabının genel çerçevesini ve kurallarını ise ÖGK'nın temel esasları oluşturmaktadır. Çalışmanın literatür kısmında tüm ayrıntılarıyla anlatılan bu esaslar ve kurallara göre öğretmen kılavuz kitabı hazırlanmıştır.

ÖGK'nın örnek-hatırlama düzeyinde öğretim, tanım-hattrlama düzeyinde öğretim, uygulama düzeyinde öğretim ve yaratma düzeyinde öğretim olmak üzere 4 öğrenme aşaması her haftaya serpiştirilmiştir. Çalışmanın içerik düzeyinde olgu, zarfları; kavram, zarf çeşitlerini; işlem, zarf çeşitlerinin kullanımını; ilke ise zarf çeşitlerinin kullanımına ilişkin kuralları kapsamaktadır. Türkçe dersinde ortaokul 7. sinıf öğrencilerine uygulanacak olan şablonun teması "kişisel gelişim", konusu "zarflar", kazanımı ise "zarfların metnin anlamına olan katkısını açıklar.” şeklindedir. Öğretmen her hafta derse başlamadan önce kuralları gözden geçirir. Bu süreçte öğrenme düzeylerinin her aşamasında (sunu, alıştırma, değerlendirme) kavram öğretim tekniklerinden yararlanılır.

\section{4. Verilerin analizi}

Araştırma sonucunda elde edilen verilerin analizinde nicel ve nitel veri analiz yöntemleri kullanılmıştır. Nicel verilerin analizinde SPSS 22.0 paket programı kullanılmıştır. Nicel veri analizinde parametrik ya da nanparametrik testlerden hangisinin kullanılacağını belirlemek için normallik testi yapılmıştır. Ön test ve son test verileri normal dağılım gösterdiği için verilerin analizinde parametrik testlerden olan eşleştirilmiş gruplar $t$ testi kullanılmıştır. Nitel verilerin analizinde ise içerik analizi kullanılmıştır. Araştırmanın amaçları ve problemleri göz önünde bulundurularak;

1. Uygulamaya katılan öğrencilerin demografik bilgilerine ilişkin bilgilerin belirlenmesinde frekans, yüzde,

2. Deney ve kontrol grubu öğrencilerinin ön test ve son test sonuçları açısından başarıları arasında anlamlı farklılık olup olmadığını belirlemek için bağımsız gruplar $t$ testi,

3. Deney grubu öğrencilerinin ön test ve son test puanları arasında anlamlı bir farklılık olup olmadığını belirlemek amacıyla eşleştirilmiş gruplar $t$ testi,

4. Uygulanan kuramın deney grubu öğrencilerinin başarıları üzerinde ne düzeyde etkili olduğunu belirlemek amacıyla etki büyüklüğü $\left(n^{2}\right)$ değeri hesaplanmıştır.

5. Uygulanan öğretim yöntemine yönelik deney grubu öğrencilerinin görüşlerini belirlemek amacıyla içerik analizi kullanılmıştır.

\section{Bulgular}

Araştırmanın bu bölümünde araştırma sorularına yönelik nicel ve nitel verilerin analizinden elde edilmiş bulgulara yer verilmiştir.

\section{1. Araştırmanın nicel boyutu ile ilgili bulgular}

Öge Gösterim Kuramına dayalı kavram öğretiminin ortaokul 7. sınıf öğrencilerinin başarılarına etkisini belirlemek amacıyla araştırmanın birinci sorusuna yönelik deney ve kontrol grubu öğrencilerine Kavram Başarı Testi ön test ve son test olarak uygulanmıştır. Bu doğrultuda öncelikle akademik başarı ön bilgi düzeylerine yönelik Kolmogorov Smirnov Normallik testi ve Levene's testi

\footnotetext{
Adres | Address

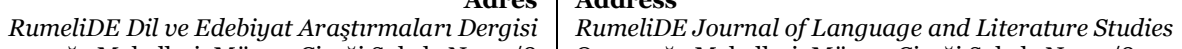
Osmanağa Mahallesi, Mürver Çiçeği Sokak, No:14/8 $\quad$ Osmanağa Mahallesi, Mürver Çiçeği Sokak, No:14/8 Kadıköy - İSTANBUL / TÜRKIYE 34714 Kadıköy - ISTANBUL / TURKEY 34714 e-posta: editor@rumelide.com e-mail: editor@rumelide.com, tel: +90 505 7958124, +90 2167730616 phone: +90 505 7958124, +90 2167730616
} 
sonuçlarına ve betimsel istatistik sonuçlarına yer verilmiştir. Ardından Öge Gösterim Kuramı ile kavram öğretiminin öğrencilerin akademik başarıları üzerinde anlamlı bir farklılık olup olmadığını belirlemek amacıyla t testi analizi sonuçlarına yer verilmiştir.

Deney işlemine başlamadan önce öğrencilerin ön bilgi düzeylerini belirlemek ve grupların eşit bir şekilde oluşturulmasını sağlamak amacıyla deney ve kontrol grubu öğrencilerine Kavram Başarı Testi ön test olarak uygulanmıştır. Elde edilen verilere öncelikle Kolmogorov Smirnov normallik testi ve grupların homojenliğini belirlemek için Levene's testi yapılmıştır. Analizler Tablo 3 ve Tablo 4’te verilmiştir.

Tablo 3. Kavram başarı testi verilerinden elde edilen puanların Kolmogorov Smirnov normallik testi sonuçları

\begin{tabular}{llll} 
Gruplar & İstatistik & sd & $\mathrm{p}$ \\
\hline Deney Grubu &, 127 & 22 & .20 \\
Kontrol Grubu &, 165 & 23 & .10
\end{tabular}

Kavram Başarı Testi ön test verilerinden elde edilen puanların Kolmogorov Simirnov normallik testi sonuçları incelendiğinde deney ve kontrol gruplarının ön test verilerinin (Deney Grubu ( $\mathrm{p}=.10 ; \mathrm{p}>.05$ ), Kontrol Grubu ( $\mathrm{p}=.20 ; \mathrm{p}>.05)$ ) normal dağılım gösterdiği tespit edilmiştir. Kavram Başarı Testi ön test verilerinin Levene's testi sonuçları Tablo 4'te verilmiştir.

Tablo 4. Kavram başarı testi verilerinden elde edilen puanların Levene's testi sonuçları

\begin{tabular}{lllll} 
& Levene's & $\mathrm{Sd} 1$ & $\mathrm{Sd} 2$ & $\mathrm{P}$ \\
\hline Ön test & .011 & 1 & 43 & .91
\end{tabular}

Tablo 4 incelendiğinde Levene's testi sonucunda grupların varyansının homojen olduğu $(p=.91 ; p>.05)$ görülmektedir.

Kavram başarı testinde elde edilen veriler normal dağılım gösterdiği için verilerin analizinde parametrik testlerden olan eşleştirilmiş gruplar t testi kullanılmıştır.

Kavram başarı testi verilerinin ön test ve son test puanlarının deney ve kontrol grupları arasında karşılaştırması için bağımsız gruplar t testi yapılmış ve Tablo 5’te sunulmuştur.

Tablo 5. Kavram başarı testi puanlarının gruplar arası karşılaştırması için yapılan bağımsız gruplar t-testi

\begin{tabular}{lllllllll}
\hline Puan & Cinsiyet & $\mathrm{N}$ & $\mathrm{X}_{\text {ort }}$ & $\mathrm{SS}$ & $\mathrm{Shx}$ & $\mathrm{t}$ & $\mathrm{sd}$ & $\mathrm{P}$ \\
\hline \multirow{2}{*}{ Ön test } & Kontrol Grubu & 23 & 10,57 & 3,42 & $\mathrm{0}, 71$ & $\mathrm{0}, 94$ & 43,00 & 0,355 \\
\cline { 2 - 9 } & Deney Grubu & $\mathbf{2 2}$ & 9,59 & 3,57 & 0,76 & & & \\
\hline \multirow{2}{*}{ Son test } & Kontrol Grubu & 23 & $\mathbf{1 4 , 0 0}$ & 4,50 & 0,94 & $-3,12$ & 39,81 & 0,003 \\
\cline { 2 - 9 } & Deney Grubu & 22 & $\mathbf{1 8 , 8 2}$ & 5,75 & 1,22 & & & \\
\hline
\end{tabular}

Tablo 5 incelendiğinde, deney ve kontrol grubu öğrencilerinin kavram başarı testinden aldıkları ön test puanlarının birbirine yakın olduğu (Deney grubu $\bar{x}=9,59$, Kontrol grubu $\bar{x}=10,57$ ), ön test puanları arasındaki farklılaşmanın istatistiksel olarak anlamlı olmadığı görülmektedir (p>0,05). Buna göre öğrencilerin çalışma öncesi seviyelerinin birbirine yakın olduğu söylenebilir.

\begin{tabular}{r|l} 
Adres & Address \\
RumeliDE Dil ve Edebiyat Araşțrmaları Dergisi & RumeliDE Journal of Language and Literature Studies \\
Osmanağa Mahallesi, Mürver Çiçeği Sokak, No:14/8 & Osmanağa Mahallesi, Mürver Çiçeği Sokak, No:14/8 \\
Kadıöy - İSTANBUL / TÜRKIYY 34714 & Kadıköy - ISTANBUL / TURKEY 34714 \\
e-posta: editor@rumelide.com & e-mail: editor@rumelide.com, \\
tel: +90 505 7958124, +90 216773 o 616 & phone: +90 505 7958124, +90 216773 o 616
\end{tabular}


The effect of concept teaching based on component display theory on 7th grade students' achievements in Turkish lesson / T. Y. Cevher; S. Ungan (pp. 30-48)

Deney ve kontrol grubu öğrencilerinin kavram başarı testinden aldıkları son test puanlarında (Deney grubu $\bar{x}=18,82$, Kontrol grubu $\bar{x}=14,00$ ) deney grubu lehine tespit edilen farklllaşmanın istatistiksel olarak anlamlı olduğu görülmektedir ( $>>0,05)$. Buna göre, yapılan deneysel çalışmanın deney grubundaki öğrencilerinde anlamlı düzeyde gelişime katkı yaptığı söylenebilir.

Ancak deney gurubunun çalışma öncesi ve çalışma sonrası puanları da karşılaştırılarak deneysel çalışmanın etkisinin grup içerisindeki verimliliğini göstermesi gerekir. Deney grubu öğrencilerinin ön test ve son test puanları arasında anlamlı bir farklılık olup olmadığını belirlemek amacıyla eşleştirilmiş gruplar t testi analizi yapılmıştır. Analiz sonuçları Tablo 6'da verilmiştir.

Tablo 6. Deney grubu kavram başarı testi ön test son test puanlarının karşılaştırması için yapılan eşleştirilmiş gruplar t-testi

\begin{tabular}{llllllllll}
\hline \multicolumn{9}{c}{ Gruplararası istatistik } & \multicolumn{2}{c}{ Grup Ortalaması } & T Testi \\
\hline Puan & $\mathrm{N}$ & $\mathrm{X}_{\text {ort }}$ & $\mathrm{SS}$ & $\mathrm{Sh}_{\mathrm{x}}$ & $\mathrm{X}_{\text {ort }}$ & $\mathrm{SS}$ & $\mathrm{t}$ & $\mathrm{sd}$ & $\mathrm{P}$ \\
\hline Ön test & 22 & 9,59 & 3,57 & $\mathrm{0,76}$ & $-6,27$ & 4,43 & $-9,48$ & 44,00 & o,ooo \\
\hline Son test & 22 & 18,82 & 5,75 & 1,22 & & & & & \\
\hline
\end{tabular}

Tabloda 6'da görüldüğü gibi, deney grubunun kavram başarı testi puanları deneysel çalışma öncesi 9,59 iken deneysel çalışma sonrası 18,82 olmuştur. Ön test ve son test puanları arasında son test puanları lehine ortaya çıkan farklılaşma $\mathrm{p}<0,001$ düzeyinde anlamlı bulunmuş̧tur $\left(X_{\ddot{o ̈ n} \text { test }}-X_{\text {son }}\right.$ ${ }_{\text {test }}=6,27 ; \mathrm{p}=0,000$ ). Buna göre yapılan deneysel çalışma öğrencilerin kavram başarı puanlarının artmasına anlamlı katkı sağlamıştır. Ayrıca etki büyüklüğü değeri (Eta squared) $n^{2}=0,54$ olarak hesaplanmış ve bu değerin güçlü düzeyde bir etkiye işaret ettiği görülmüştür.

Yapılan deneysel çalışmanın cinsiyete göre farklılaşıp farklılaşmadığını sınamak için bağımsız gruplar t testi yapılmış ve Tablo 7'de gösterilmiştir.

Tablo 7. Deney grubu kavram başarı testi puanlarının cinsiyete karşılaştırması için yapılan eşleştirilmiş gruplar ttesti

\begin{tabular}{llllllll}
\hline Puan & Cinsiyet & $\mathrm{N}$ & $\mathrm{X}_{\text {ort }}$ & $\mathrm{SS}$ & $\mathrm{t}$ & $\mathrm{sd}$ & $\mathrm{P}$ \\
\hline \multirow{2}{*}{ Ön test } & Kiz & 22 & 11,09 & 3,54 & 1,94 & 43,00 & 0,059 \\
\cline { 2 - 8 } & Erkek & 23 & 9,13 & 3,22 & & & \\
\hline \multirow{2}{*}{ Son test } & Kiz & 22 & 17,50 & 5,42 & 1,34 & 43,00 & 0,186 \\
\cline { 2 - 8 } & Erkek & 23 & 15,26 & 5,75 & & & \\
\hline
\end{tabular}

Tablo 7'de görüldüğ̈̈ gibi, deney grubu kavram başarı testi puanlarının cinsiyete göre karşılaştırması için yapılan bağımsız gruplar t testi sonucunda, ön test puanlarında (kızlar $X_{\text {ort }}=11$,og; erkekler $X_{\text {ort }}$ =9,13) ve son test puanlarında (kızlar $X_{\text {ort }}=17,50$; erkekler $X_{\text {ort }}=15,26$ ) arasındaki farklılaşma istatistiksel olarak anlamlı bulunmamıştır ( $\mathrm{p}>0,05)$. Kızlar ve erkekler arasında son test puanlarındaki farklılaşmanın anlamlı düzeyde olmaması, deneysel çalışmada yapılan çalışmanın kızlar ve erkekler arasında farklılık barındıran uygulamalar içermediğini göstermektedir. 


\section{2. Araştırmanın nitel boyutu ile ilgili bulgular}

Deney grubunda yer alan öğrencilerin ÖGK'ya ilişkin görüşlerini belirlemek amaciyla öğrencilere 6 soru yöneltilmiştir. Öğrencilerin sorulara verdikleri cevapların içerik analizi sonuçları tablolaştırılarak verilmiştir.

Öğrencilerin Öge Gösterim Kuramının Kullanılmasına Yönelik Görüşleri: Öğrencilere ilk olarak “Türkçe derslerinde kullanılan ÖGK ile ilgili ne düşünüyorsun?” şeklinde bir soru yöneltilmiştir. Öğrencilerin bu soruya yönelik görüşleri Tablo 8'de verilmiştir.

Tablo 8. Öğrencilerin Öge Gösterim Kuramı ile ilgili görüşleri

\begin{tabular}{lll}
\hline Kategori & $\ddot{O}_{\text {ğrenci }}$ & $F$ \\
\hline Eğlenceli olması & $\ddot{\mathrm{O}}_{1}, \ddot{\mathrm{O}}_{2}, \ddot{\mathrm{O}}_{5}, \ddot{\mathrm{O}}_{6}, \ddot{\mathrm{O}}_{7}, \ddot{\mathrm{O}}_{8}$ & 6 \\
\hline Kalıcı öğrenme & $\ddot{\mathrm{O}}_{1}, \ddot{\mathrm{O}}_{4}, \ddot{\mathrm{O}}_{7}$ & 3 \\
\hline Anlaşllır olması & $\ddot{\mathrm{O}}_{3}, \ddot{\mathrm{O}}_{7}, \ddot{\mathrm{O}}_{8}$ & 3 \\
\hline Derste aktif olma imkânı & $\ddot{\mathrm{O}}_{5}, \ddot{\mathrm{O}}_{6}, \ddot{\mathrm{O}}_{10}$ & 3 \\
\hline Uygulamalı olması & $\ddot{\mathrm{O}}_{2}, \ddot{\mathrm{O}}_{9}$ & 2 \\
\hline
\end{tabular}

Tablo 8 incelendiğinde öğrenciler sırasıyla Öge Gösterim Kuramının eğlenceli olması, kalıcı öğrenme sağlaması, anlaşılır olması, derste aktif olma imkânı sunması ve uygulamalı olması yönünde görüş bildirmişlerdir. Öğrencilerin bu görüşlerinden bazıları doğrudan alıntılanarak aşağıda verilmiştir.

Öğrencilerden ${ }_{2}$ Öge Gösterim Kuramının eğlenceli ve uygulama imkânı sunduğunu;

"Bu şekilde ders işlemek daha eğlenceliydi çünkü daha çok uygulama yapıp daha çok oyun oynuyoruz sadece yazıyla değil uygulayarak öğreniyoruz."

Öğrencilerden $\ddot{O}_{1}$ Öge Gösterim Kuramının eğlenceli ve kalıcı olduğunu;

"Ben çok eğlendim. Güle oynaya ders işledik. Bizler küçük olduğumuz için eğlenceli dersleri daha çok seviyoruz. Bu açıdan dersler daha kahıc oluyor. Dersleri bu yöntemle anlatmak daha unutulmaz oluyor. Sanki dün gibi aklımızda kahyor.”

Öğrencilerden $\ddot{O}_{5}$ Öge Gösterim Kuramının derste aktif olma imkânı sunduğunu;

"Derslerde daha çok uygulama yaptığımız için daha çok oyun oynuyoruz, sadece yazı yazarak değil derse daha çok katılarak uygulama yapıyoruz." şeklinde ifade etmiştir.

Öğrencilerin Öge Gösterim Kuramınn Uygulama Sürecinin Olumlu Yönlerine İlişkin Görüşleri: Öğrencilere "Türkçe derslerinde kullanılan Öge Gösterim Kuramı ile ders işlenmesinin olumlu tarafları nelerdir?” şeklinde bir soru sorulmuştur. Öğrencilerin bu soruya yönelik görüşleri Tablo 9'da sunulmuştur.

Tablo 9. Öğrencilerin Öge Gösterim Kuramı ile ders sürecinin olumlu yönlerine ilişkin görüşleri

\begin{tabular}{|c|c|}
\hline Kategori & Öğrenci \\
\hline Daha çok etkinlik yapmak & $\ddot{\mathrm{O}}_{1}, \ddot{\mathrm{O}}_{2}, \ddot{\mathrm{O}}_{5}, \ddot{\mathrm{O}}_{7}, \ddot{\mathrm{O}}_{9}$ \\
\hline $\begin{array}{r}\text { Adres } \\
\text { RumeliDE Dil ve Edebiyat Araştırmaları Dergisi } \\
\text { Osmanağa Mahallesi, Mürver Çiçeği Sokak, No:14/8 } \\
\text { Kadıköy - İSTANBUL / TÜRKIYE } 34714 \\
\text { e-posta: editor@rumelide.com } \\
\text { tel: }+905057958124,+902167730616\end{array}$ & $\begin{array}{l}\text { Address } \\
\text { RumeliDE Journal of Language and Literature Studies } \\
\text { Osmanağa Mahallesi, Mürver Çiçeği Sokak, No:14/8 } \\
\text { Kadıköy - ISTANBUL / TURKEY } 34714 \\
\text { e-mail: editor@rumelide.com, } \\
\text { phone: +90 505 7958124, +90 } 216773 \text { o } 616\end{array}$ \\
\hline
\end{tabular}


The effect of concept teaching based on component display theory on 7th grade students' achievements in Turkish lesson / T. Y. Cevher; S. Ungan (pp. 30-48)

Örneklerin fazla olması

Daha anlaşılır olması

İlgi çekici olması

Derse aktif katılım

$\begin{array}{ll}\ddot{\mathrm{O}}_{1}, \ddot{\mathrm{O}}_{6}, \mathrm{O}_{7} & 3 \\ \ddot{\mathrm{O}}_{2}, \ddot{\mathrm{O}}_{3}, \ddot{\mathrm{O}}_{10} & 3 \\ \ddot{\mathrm{O}}_{8}, \ddot{\mathrm{O}}_{9} & 2 \\ \ddot{\mathrm{O}}_{4}, \ddot{\mathrm{O}}_{10} & 2\end{array}$

Tablo 9 incelendiğinde; öğrencilerin Öge Gösterim Kuramı ile uygulama sürecinin olumlu yönlerine ilişkin; daha çok etkinlik yapmak, örneklerin fazla olması, daha anlaşılır olması, ilgi çekici olması ve derse aktif katılım sağlaması yönünde görüş belirttikleri görülmektedir. Öğrencilerin bu görüşlerinden bazıları doğrudan alıntılanarak aşağıda verilmiştir.

Öğrencilerden $\ddot{O}_{1}$ Öge Gösterim Kuramı ile ders işleme sürecinin olumlu yönü olarak derste daha çok etkinlik yapıldığını;

"Diğer derslerde hiç etkinlik yapmıyoruz. Ama bu derste daha fazla etkinlik yaptığımız için fazlasıyla olumlu yönü vardır."

Öğrencilerden $\ddot{O}_{2}$ Öge Gösterim Kuramı ile ders işleme sürecinin olumlu yönü olarak daha anlaşılır olduğunu;

"Daha çok tekrar yaptığımız ve birçok farklı etkinlik yaptığımız için ders çok güzeldi ve dersi daha çok iyi anladım."

Öğrencilerden $\ddot{O}_{10}$ Öge Gösterim Kuramı ile ders işleme sürecinin olumlu yönü olarak derse aktif katıldığını;

“Ders daha zevkli geçtiği için dersi daha iyi anlyorum ve daha çok parmak kaldırıorum.” sözleri ile ifade etmiştir.

Öğrencilerin Öge Gösterim Kuramını Uygulama Sürecinin Olumsuz Yönlerine İlişkin Görüşleri: Öğrencilere "Türkçe derslerinde kullanılan Öge Gösterim Kuramı ile ders işlenmesinin olumsuz tarafları nelerdir?” şeklinde bir soru yöneltilmiştir. Öğrencilerin bu soruya yönelik görüşleri Tablo 10’da sunulmuştur.

Tablo 10. Öğrencilerin Öge Gösterim Kuramı ile ders sürecinin olumsuz yönlerine ilişkin görüşleri

\begin{tabular}{lll} 
Kategori & Öğrenci & $\mathrm{f}$ \\
\hline Tekrarların fazla olması & $\ddot{\mathrm{O}}_{3}, \ddot{\mathrm{O}}_{4}$ & 2 \\
Olumsuzluk yaşamayan & $\ddot{\mathrm{O}}_{1}, \ddot{\mathrm{O}}_{2}, \ddot{\mathrm{O}}_{5}, \ddot{\mathrm{O}}_{6}, \ddot{\mathrm{O}}_{7}, \ddot{\mathrm{O}}_{8}, \ddot{\mathrm{O}}_{9}, \ddot{\mathrm{O}}_{10}$ & 8
\end{tabular}

Tablo 10 incelendiğinde; 2 öğrencinin Öge Gösterim Kuramı ile ders sürecinin olumsuz taraflarına yönelik tekrarların fazla olması yönünde görüş bildirdiği görülürken 8 öğrenci bu süreçte herhangi bir olumsuzluk yaşamadığı yönünde görüş bildirmiştir. Uygulama sürecinin olumsuz yönlerine ilişkin görüşlerinden bazıları doğrudan alıntılanarak aşağıda verilmiştir.

Öğrencilerden Ö$_{3}$ Öge Gösterim Kuramı ile ders işleme sürecinin olumsuz yönü olarak derste çok etkinlik yapıldı̆̆ını; 
"Öğretmenimiz bu derslerde bence çok tekrar yapıyor bu yüzden dersten bazen sıkılıyorum. Bazı konuları öğrendiğim hâlde tekrardan işlemek hoşuma gitmiyor.” sözleriyle ifade etmiştir.

Öğrencilerin Öge Gösterim Kuramınn Kullanılmasın İstedikleri Derslere ve Bunun Nedenlerine İlişkin Görüşleri: Öğrencilere “Türkçe derslerinde kullanılan Öge Gösterim Kuramının diğer derslerde de kullanılmasını ister misiniz? Neden?” şeklinde bir soru yöneltilmiştir. Öğrencilerin bu soruya yönelik görüşleri Tablo 11'de sunulmuştur.

Tablo 11. Öğrencilerin Öge Gösterim Kuramının kullanılmasını istedikleri derslere ve bunun nedenlerine ilişkin görüşleri

\begin{tabular}{lll}
\hline Kategori & $\ddot{O}_{\text {ğrenci }}$ & $\mathrm{f}$ \\
\hline Fen Bilgisi & & 2 \\
\hline Dersin zor olması & $\ddot{\mathrm{O}}_{6}, \ddot{O}_{10}$ & 2 \\
\hline Konuların fazla olması & $\ddot{O}_{3}, \ddot{O}_{4}$ & 3 \\
\hline Matematik & & 1 \\
\hline Dersin zor olması & $\ddot{\mathrm{O}}_{2}, \ddot{\mathrm{O}}_{7}, \ddot{\mathrm{O}}_{9}$ & \\
\hline Sebep belirtmeyen & $\ddot{\mathrm{O}}_{1}$ & 3 \\
\hline İngilizce & & $\ddot{\mathrm{O}}_{5}, \ddot{O}_{6}, \ddot{\mathrm{O}}_{8}$ \\
\hline Kelime öğrenme &
\end{tabular}

Tablo 11 incelendiğinde öğrenciler Öge Gösterim Kuramının en çok Fen Bilgisi ve Matematik derslerinde, daha sonra İngilizce derslerinde kullanılmasını istediklerine yönelik görüş bildirmişlerdir. Fen Bilgisi derslerinde kullanılmasına yönelik görüş bildiren öğrenciler bu dersin zor olması ve konuların fazla olmasını gerekçe göstermiştir. Matematik dersinde kullanılmasına yönelik görüş bildiren öğrencilerin büyük bir kısmı dersin zor olmasını gerekçe gösterirken İngilizce dersinde bu kuramın kullanılmasına yönelik görüş bildiren öğrenciler ise kelime öğrenmeye yardımcı olabileceğini sebep olarak göstermiştir. Öğrencilerin görüşlerine yönelik bazı doğrudan alıntılara aşă̆ıda yer verilmiştir.

Öğrencilerden Öge Gösterim Kuramının Fen Bilgisi dersinde kullanılmasını isteyen $\ddot{O}_{10}$;

"Evet isterim. Fen Bilgisi dersi zor olduğu için, bu dersi daha iyi öğrenmek için bu etkinlikleri kullanılmak iyi olur." sözleriyle ifade etmiştir.

Öğrencilerden Öge Gösterim Kuramının Matematik dersinde kullanılmasını isteyen ${ }_{7}$;

"Matematik dersinde kullanlmasın isterim. Çünkü matematik dersi bana çok zor geliyor ve yazlllardan düşük not alyyorum. Matematik dersini böyle işlersek daha iyi öğrenebilirim.” Sözleriyle ifade etmiştir.

Öğrencilerden Öge Gösterim Kuramının İngilizce dersinde kullanılmasını isteyen $\ddot{O}_{6}$;

"Evet İngilizce dersinde kullamlmasın isterim. İngilizce dersinde çok kelime ezberlediğimiz için bu yöntemle daha kolay öğrenirim diye düşünüyorum.” sözleriyle ifade etmiştir. 
The effect of concept teaching based on component display theory on 7th grade students' achievements in Turkish lesson / T. Y. Cevher; S. Ungan (pp. 30-48)

Öğrencilerin Öge Gösterim Kuramı ile Yürütülen Ders Sürecinin Başarllarına Etkisine İlişkin Görüşleri: Öğrencilere "Öge Gösterim Kuramı ile yürütülen ders süreci senin Türkçe dersindeki başarını etkiledi mi?” şeklinde bir soru yöneltilmiştir. Öğrencilerin bu soruya verdikleri cevaplar Tablo 12'de sunulmuştur.

Tablo 12. Öğrencilerin Öge Gösterim Kuramı ile yürütülen ders sürecinin başarılarına etkisine yönelik görüşleri

Kategori

Öğrenci $\mathrm{f}$

Kalıcı öğrenme

$\ddot{\mathrm{O}}_{1}, \ddot{\mathrm{O}}_{4}, \ddot{\mathrm{O}}_{6}, \ddot{\mathrm{O}}_{7}, \ddot{\mathrm{O}}_{10}$

5

Konuyu daha iyi öğrenme

$\ddot{\mathrm{O}}_{2}, \ddot{\mathrm{O}}_{3}, \ddot{\mathrm{O}}_{9}$

Sınav başarısı sağlama

$\ddot{\mathrm{O}}_{5}, \ddot{\mathrm{O}}_{8}, \ddot{\mathrm{O}}_{9}$

Tablo 12 incelendiğinde öğrenciler Öge Gösterim Kuramı ile yürütülen ders sürecinin başarılarına etkisine yönelik sırasıyla kalıcı öğrenme, konuyu daha iyi öğrenme ve sınav başarısı sağladığı yönünde görüş bildirmişlerdir. Bu konudaki bazı öğrenci görüşleri doğrudan alıntılanarak aşağıda verilmiştir.

Öğrencilerden $\ddot{O}_{6}$ Öge Gösterim Kuramı ile ders işleme sürecinin başarıya etkisine yönelik kalıcı öğrenme sağladığını;

"Dersler zihin açıcı oluyor ve akılda kahyor. Derste öğrendiğim konuları hiç unutmuyorum. Bu sayede yazlllardan daha iyi not alyyorum."

Öğrencilerden $\ddot{O}_{2}$ Öge Gösterim Kuramı ile ders işleme sürecinin başarıya etkisine yönelik daha iyi öğrenme sağladı̆̆ını;

"Evet etkiledi. Derslerde yaptığımız etkinliklerle konuyu daha iyi öğrendim. Daha iyi öğrendiğim için derslerde daha başarll oldum."

Öğrencilerden Ö$_{9}$ Öge Gösterim Kuramı ile ders işleme sürecinin başarıya etkisine yönelik daha iyi öğrenme sağladığını;

"Tabi ki de evet. Bu tarzda eğitim slkıcı olmadan, derse kendimizi kaptırarak geçiyor. Bu yüzden dersi daha iyi öğreniyorum. Bütün okullarda böyle eğitim olsa tembel öğrenci olmaz. Ve herkes iyi bir meslek sahibi olabilir." sözleriyle ifade etmiştir.

Öğrencilerin Öge Gösterim Kuramı ile Yürütülen Ders Sürecinin Türkçe Dersine Yönelik İlgi ve Tutumlarına Etkisine İlişkin Görüşleri: Öğrencilere "Öge Gösterim Kuramı ile yürütülen ders süreci senin Türkçe dersine olan ilgi ve tutumunu etkiledi mi? Neden?” şeklinde bir soru yöneltilmiştir. Öğrencilerin bu soruya verdikleri cevaplar Tablo 13’te verilmiştir.

Tablo 13. Öğrencilerin Öge Gösterim Kuramı ile yürütülen ders sürecinin Türkçe dersine yönelik ilgi ve tutumlarına etkisine yönelik görüşleri

\begin{tabular}{lll}
\hline Kategori & Öğrenci & $\mathrm{f}$ \\
\hline Olumlu Etki & & \\
\hline Dersin eğlenceli geçmesi & $\ddot{\mathrm{O}}_{1}, \ddot{\mathrm{O}}_{2}, \ddot{\mathrm{O}}_{6}, \ddot{\mathrm{O}}_{10}$ & 4 \\
\hline Başarııı arttırması & $\ddot{\mathrm{O}}_{5}, \ddot{\mathrm{O}}_{9}$ & 2 \\
\hline Dersin anlaşılır olması & $\ddot{\mathrm{O}}_{7}$ & 1 \\
\hline
\end{tabular}

Osmanağa Mahallesi, Mürver Çiçeği Sokak, No:14/8 Osmanağa Mahallesi, Mürver Çiçeği Sokak, No:14/8

Kadıköy - İSTANBUL / TÜRKIYE 34714 Kadıköy - ISTANBUL / TURKEY 34714

e-posta: editor@rumelide.com e-mail: editor@rumelide.com,

tel: +90 505 7958124, +90 2167730616 phone: +90 505 7958124, +90 2167730616 


\begin{tabular}{lll}
\hline Olumsuz Etki & & \\
\hline Tekrarların fazla olması & $\ddot{O}_{3}$ & 1 \\
\hline Hiç Etkisi Olmayan & & \\
\hline & $\ddot{0}_{4}, \ddot{O}_{8}$ & 2 \\
\hline
\end{tabular}

Tablo 13 incelendiğinde Öge Gösterim Kuramı ile yürütülen ders sürecinin Türkçe dersine yönelik ilgi ve tutuma etkisine yönelik öğrencilerin büyük bir kısmı olumlu etki olduğuna yönelik görüş bildirirken 1 öğrenci olumsuz etkilediğini, 2 öğrenci ise hiç etki etmediğini söylemiştir. Olumlu etki ettiğini belirten öğrenciler gerekçe olarak sırasıyla dersin eğlenceli geçmesi, başarıyı arttırması ve dersin anlaşılır olmasını gösterirken olumsuz etki olarak 1 öğrenci tekrarların fazla olmasını gerekçe göstermiştir. Ö̆̆grenci görüşlerine yönelik bazı doğrudan alıntılara aşağıda yer verilmiştir.

Olumlu değişikliğe sebep olan öğrenci görüşlerinden

Öğrencilerden $\ddot{O}_{10}$ Öge Gösterim Kuramı ile ders işleme sürecinin

"Evet etkiledi. Bundan sonra Türkçe derslerinin bu modelle işlenmesini isterim. Çünkü dersler daha eğlenceli geçiyor. Bu yüzden Türkçe derslerini daha çok seviyorum.”

Olumsuz değişikliğe sebep olan öğrenci görüşlerinden

Öğrencilerden $\ddot{O}_{3}$ Öge Gösterim Kuramı ile ders işleme sürecinin olumsuz yönünü

"Evet bu derste çok fazla tekrar yapmamız yüzünden dersler benim için çok sıkıcı geçiyor. Türkçe dersini sevdiğim hâlde fazla tekrar yapmak bu dersten sıkllmama sebep oldu.” sözleriyle ifade etmiştir.

\section{Tartışma}

$\mathrm{Bu}$ çalışmanın amacı, öğrenme kuramlarından biri olan Öge Gösterim Kuramı (Component Display Theory) temel alınarak yapılan kavram öğretiminin ortaokul 7. sınıf öğrencilerinin akademik başarıları üzerine etkisini inceleyerek bu konudaki öğrenci görüşlerini belirlemektir. Bu amaç doğrultusunda elde edilen bulgular yorumlanarak ve ilgili literatürle ilişkilendirilerek tartışmalar başlıklar hâlinde sunulmuştur.

Öge Gösterim Kuramının Öğrencilerin Başarıları Üzerine Etkisi: Araştırmada deney işlemine başlamadan önce deney ve kontrol grubunun eşit bir şekilde oluşturulmasını sağlamak ve öğrencilerin ön bilgi düzeylerini belirleme amacıyla uygulanan kavram başarı testinden elde edilen bulgular incelendiğinde; deney grubu öğrencilerinin ön test puan ortalamaları $\left({ }^{\bar{x}}=9,59\right)$ ile kontrol grubu öğrencilerinin ön test puan ortalamalarının $\left({ }^{\bar{x}}=10,57\right)$ birbirine yakın olduğu ve gruplar arasında ön test puanları bakımından anlamlı bir farklılık olmadığı belirlenmiştir. Bu bulgudan hareketle araştırmaya katılan öğrencilerin akademik başarıları açısından birbirine denk olduğu söylenebilir. Deney ve kontrol gruplarının ön bilgi düzeylerinin birbirine yakın olması uygulanan yöntemin karşılaştırılabilmesi için önemli bir avantaj sağladığı düşünülmektedir.

\footnotetext{
\begin{tabular}{r|l} 
Adres & Address \\
RumeliDE Dil ve Edebiyat Araşttrmalar Dergisi & RumeliDE Journal of Language and Literature Studies
\end{tabular} Osmanağa Mahallesi, Mürver Çiçeği Sokak, No:14/8 Osmanağa Mahallesi, Mürver Çiçeği Sokak, No:14/8 Kadıköy - İSTANBUL / TÜRKIYE 34714 Kadıköy - ISTANBUL / TURKEY 34714 e-posta: editor@rumelide.com e-mail: editor@rumelide.com, tel: +90 505 7958124, +90 2167730616 phone: +90 505 7958124, +90 2167730616
} 
The effect of concept teaching based on component display theory on 7th grade students' achievements in Turkish lesson / T. Y. Cevher; S. Ungan (pp. 30-48)

Araştırmada elde edilen bulgulara göre, deney grubu öğrencilerinin kavram başarı testi son test puanlarının ortalamasının $\left({ }^{\bar{x}}=18,82\right)$ kontrol grubu öğrencilerinin kavram başarı testi son test puanlarının ortalamasından $\left({ }^{\bar{x}}=14,00\right)$ daha yüksek olduğu tespit edilmiştir. Bu doğrultuda Öge Gösterim Kuramı ile öğrenim gören deney grubu öğrencileri ile programa dayalı öğrenim gören kontrol grubu öğrencileri arasında akademik başarı açısından deney grubu lehine anlamlı bir farklılık olduğu görülmüsstür. Öge Gösterim Kuramına dayalı kavram öğretiminin uygulandığı deney grubu öğrencilerinin akademik başarılarının yüksek olmasının sebebinin, bu kuramın derslerde öğrenciyi daha aktif kılması, dersin eğlenceli geçmesi ve yapılan tekrarlarla öğrenilenlerin kalıcı öğrenmeyi sağlaması olduğu söylenebilir. Deney işlemi sonrasında öğrencilerle yapılan görüşmeler de araştırmanın bu sonucunu destekler niteliktedir. Elde edilen bu sonuç literatürde Öge Gösterim Kuramının akademik başarıyı arttırmada programa dayalı öğretime göre daha etkili olduğunu belirten bazı araştırma sonuçlarıyla (Von Hurst, 1984; Karataş Coşkun, 1999; Dede, 2003; Eryılmaz, 2010) paralellik göstermektedir. Bununla birlikte Öge Gösterim Kuramı ile kavram öğretiminin geleneksel kavram öğretim yöntemlerinden farklı olarak bir kavramın öğretiminde o kavramın tanımının, özelliklerinin, özellik olmayanlarının, örneklerinin ve örnek olmayanlarının verilerek öğretilmesinin başarıyı arttırmada etkili olduğu düşünülmektedir. Bu görüşü destekleyen Kılıç (2008), "kavramların öğretiminde kavram analizi yönteminin akademik başarıya ve bilişsel esnekliğe etkisi” adlı çalışmasının sonucunda bir kavramın tanımının, özelliklerinin, özellik olmayanlarının, örneklerinin ve örnek olmayanlarının verilmesinin kavram öğrenmeyi kolaylaştırdığı ve akademik başarıyı da artırdığı sonucuna ulaşmıştır. Bu doğrultuda Öge Gösterim Kuramı ile kavram öğretimi sürecinin başarıyı arttırmada önem taşıdığı söylenebilir.

Kontrol grubu öğrencilerinin deney grubundaki öğrencilere göre başarı oranlarının son testte düşük olduğu belirlenmiştir. Bu sonucun sınıf içi gözlemlerden de anlaşıldığı gibi programa dayalı öğretim yönteminin kullanıldığı ders sürecinde soru-cevap, anlatım ve ders kitaplarındaki etkinliklerin yapılması şeklinde derslerin işlenmesi, soyut bir kavramın öğretiminde yetersiz kalması durumundan kaynaklandığı düşünülmektedir. Programa dayalı öğretim yöntemlerinin öğrencilerin kavramları anlamaları ve öğrenmelerinde etkinliğinin az olduğu sonucu, konuyla ilgili birçok çalışmanın sonucuyla paralellik göstermektedir (Akbaş, 2008; Kılıç, 2008; Kurt, 2018; Tan, 2008). Dolayısıyla programa dayalı öğretimin yanı sıra özellikle soyut kavramların öğretiminde, farklı kavram öğretim tekniklerinin kullanımı daha etkili bir kavram öğretiminin gerçekleşmesini sağlayacaktır.

Öğrencilerin Öge Gösterim Kuramına Yönelik Görüşleri: Araştırmada elde edilen bulgular sonucunda Öge Gösterim Kuramına yönelik görüşlerinin belirlenmesi hedeflenen deney grubu öğrencilerinin genel olarak bu kurama yönelik olumlu düşüncelere sahip oldukları görülmüştür. Bunun sebebi olarak Öge Gösterim Kuramı ile ders sürecinin eğlenceli olması, kalıcı öğrenme sağlaması, anlaşılır olması, ilgi çekici olması, derste aktif olma imkânı sunması ve uygulamalı olması yönünde görüş bildirmişlerdir. Bu sonuca paralel olarak; Eryılmaz (2009), Öge Gösterim Kuramına göre tasarlanan kavram öğretiminin öğrencilerin, tutumlarına etkisini de incelediği çalışmasında öğrencilerin bu kurama olumlu tutum geliştirdikleri yönünde bir sonuca ulaşmıştır. Öğrencilerin bu kurama ilişkin olumlu tutumlarının sebebi kuramın öğretimi sırasında kullanılan kavram öğretim tekniklerinin kullanılması da olabilir. Sarıgül (2009)'ün çalışmasında öğrencilerin yapılandırılmış grid, kavram haritası teknikleri ile kavram öğretimi tekniklerine ilişkin öğrencilerin olumlu tutum geliştirdiklerini ifade etmesi de bu sonucu desteklemektedir. 
Öge Gösterim Kuramı ile yürütülen ders sürecinin Türkçe dersine yönelik ilgi ve tutuma etkisi konusunda öğrencilerin büyük bir kısmı olumlu etkisi olduğuna yönelik görüş bildirirken 1 öğrenci olumsuz etkilediğini, 2 öğrenci ise hiç etkisi olmadığını söylemiştir. Olumlu etkisi olduğunu belirten öğrenciler gerekçe olarak sırasıyla dersin eğlenceli geçmesi, başarıyı arttırması ve dersin anlaşılır olmasını göstermişlerdir. Öğrencilerin bu olumlu görüşlerinin kavram öğretim modelinin içerisinde kullanılan kavram öğretim teknikleri ile desteklenerek hazırlanan etkinliklerden kaynaklandığı düşünülmektedir. Bu sonuca paralel olarak Öztürk (2011), çalışmasında kavram haritaları, yapılandırılmış grid ve tanılayıcı dallanmış ağaç teknikleri kullanılarak yürütülen ders sürecinin öğrencilerin derse ilişkin olumlu tutum geliştirdikleri sonucuna ulaşmıştır. Olumsuz görüş olarak tekrarların fazla olmasını gerekçe gösteren bir öğrencinin bu görüşünün sebebi ise genel olarak Öge Gösterim Kuramının içerisinde bir kavramın öğretimi gerçekleştirilirken her adımda tekrar edilmesinden kaynaklandığı düşünülmektedir. Bu düşünceye paralel olarak Orhan Karsak (2018), "Merrill'in Bileşen Gösterim Kuramı’na genel bir bakış” isimli çalışmasında da bu kuramın süre sınırı olmaksızın devam eden bir süreç gerektiren bu modelin ülkemizde uygulanabirliğinin zor olmasından ve daha çok bilgisayar destekli bir sürecin bu kuramın uygulanmasını daha kolaylaştıracağından bahsetmiştir.

Öğrenciler Öge Gösterim Kuramı ile yürütülen ders sürecinin Türkçe dersindeki başarılarına etkisine yönelik sırasıyla kalıcı öğrenme, konuyu daha iyi öğrenme ve sınav başarısı sağladığı yönünde görüş bildirmişlerdir. Bunun sebebi Öge Gösterim Kuramı ile kavram öğretimi sürecinin sıkça tekrar içermesi ve kavram ile ilgili örnek çeşitliliğinin fazla olması olabilir. Bir kavramın tanımının, özelliklerinin, özellik olmayanlarının, örneklerinin ve örnek olmayanlarının verilmesinin (kavram analizi) kavram öğrenmeyi kolaylaştırdığı ve akademik başarıyı da artırdığı söylenebilir (Kılıç, 2008). Aktepe ve diğerleri (2017)'nin çalışmasında kavram öğretiminde; kavram haritalarının, kavram ağlarının, kavram karikatürlerinin ve kavram bulmacalarının kullanılmasıyla öğrenmenin daha doğru ve anlamlı bir hâl aldığı, öğrenmenin ve hatırlamanın kolaylaştığı, kavram yanılgılarının da ortadan kalktığı sonucuna varması da öğrencilerin görüşünü desteklemektedir.

Öğrenciler Öge Gösterim Kuramının en çok Fen Bilgisi ve Matematik derslerinde, daha sonra İngilizce derslerinde kullanılmasını istediklerine yönelik görüş bildirmişlerdir. Fen Bilgisi derslerinde kullanılmasına yönelik görüş bildiren öğrenciler bu dersin zor olması ve konuların fazla olmasını gerekçe göstermiştir. Matematik dersinde kullanılmasına yönelik görüş bildiren öğrencilerin büyük bir kısmı dersin zor olmasını gerekçe gösterirken İngilizce dersinde bu kuramın kullanılmasına yönelik görüş bildiren öğrenciler ise kelime öğrenmenin olmasını sebep olarak göstermiştir. Literatürde Öge Gösterim Kuramı ile kavram öğretimi çalışmalarının genel olarak Matematik derslerinde yapılmasının da öğrencilerin bu görüşleriyle paralellik gösterdiği söylenebilir (Dede, 2003; Dede, 2004; Adır Erben, 2011). Öğrencilerin bu görüşü, kullanılan kavram öğretimi tekniklerinin daha çok öğrenmekte güçlük çektikleri kavramların öğretimini kolaylaştırması bakımından anlamlı görünmektedir.

\section{Sonuç ve öneriler}

Bu araştırmada, Öge Gösterim Kuramının öğrencilerin akademik başarılarına etkisi ve bu kurama yönelik öğrencilerin görüşleri incelenmiştir.

Öge Gösterim Kuramı ile yapılan kavram öğretiminin uygulandığı deney grubu ile programa dayalı öğretimin uygulandığı kontrol grubu arasındaki başarı düzeylerinin belirlenmesi bağlamında; Öge Gösterim Kuramı ile kavram öğretiminin uygulandığı deney grubu öğrencilerinin son test başarı

\footnotetext{
\begin{tabular}{r|l} 
Adres & Address \\
RumeliDE Dil ve Edebiyat Araştormalar Dergisi & RumeliDE Journal of Language and Literature Studies
\end{tabular} Osmanağa Mahallesi, Mürver Çiçeği Sokak, No:14/8 Osmanağa Mahallesi, Mürver Çiçeği Sokak, No:14/8 Kadıköy - İSTANBUL / TÜRKIYE 34714 Kadıköy - ISTANBUL / TURKEY 34714 e-posta: editor@rumelide.com e-mail: editor@rumelide.com, tel: +90 505 7958124, +90 2167730616 phone: +90 505 7958124, +90 2167730616
} 
The effect of concept teaching based on component display theory on 7th grade students' achievements in Turkish lesson / T. Y. Cevher; S. Ungan (pp. 30-48)

ortalamalarının $(\bar{x}=18,82)$ programa dayalı öğretimin uygulandığı kontrol grubu öğrencilerinin son test başarı ortalamalarından $(\bar{x}=14,00)$ daha yüksek olduğu görülmüştür. Bu sonuç Öge Gösterim Kuramı ile kavram öğretiminin başarıyı arttırmada etkili olduğunu göstermektedir.

Öge Gösterim Kuramı ile yapılan kavram öğretiminin öğrencilerin başarıları üzerine etki büyüklüğünün saptanması bağlamında; Öge Gösterim Kuramı ile kavram öğretiminin uygulandığı deney grubu öğrencilerinin ön test puanları $(\bar{x}=9,59)$ ve son test puanları $(\bar{x}=18,82)$ arasında istatistiksel olarak anlamlı bir farklılık bulunmuştur $(\mathrm{p}<0,05)$. Etki büyüklüğü değeri (Eta squared) $n^{2}=0,54$ olarak hesaplanmış ve bu değerin güçlü düzeyde bir etkiye işaret ettiği görülmüsştür.

Öge Gösterim Kuramı ile yapılan kavram öğretiminin cinsiyet değişkenine göre etki düzeyinin belirlenmesi bağlamında; Öge Gösterim Kuramı ile kavram öğretiminin uygulandığı deney grubunda yer alan öğrencilerin ön test (kızlar $X_{\text {ort }}=11,09$; erkekler $X_{\text {ort }}=9,13$ ) ve son test puanları (kızlar $X_{\text {ort }}$ $=17,50$; erkekler $\left.X_{o r t}=15,26\right)$ arasındaki farklılaşma istatistiksel olarak anlamlı bulunmamıştır (p>0,05). Kızlar ve erkekler arasında son test puanlarındaki farklılaşmanın anlamlı düzeyde olmaması, deneysel çalışmada yapılan çalışmanın kızlar ve erkekler arasında farklılık barındıran uygulamalar içermediğini göstermektedir.

Deney grubu öğrencilerinin Öge Gösterim Kuramı ile yapılan kavram öğretimine yönelik görüşlerinin belirlenmesi bağlamında ise; Öge Gösterim Kuramı ile kavram öğretiminin uygulandığı deney grubunda yer alan öğrencilerin Öge Gösterim Kuramına yönelik genel olarak olumlu düşüncelere sahip oldukları ve diğer derslerde de bu kuramın kullanılmasını istedikleri tespit edilmiştir.

Araştırma bulgularından elde edilen sonuçlar doğrultusunda aşağıdaki önerilere yer verilmiştir;

1. Türkçe eğitimi kavram öğretiminde öğrenci başarısını arttırmak ve öğrencilerin derse ilgisini çekmek amacıyla öğretim programında yer alan diğer kazanım ve konular Öge Gösterim Kuramına uyarlanarak ders planları hazırlanabilir.

2. Araştırmada elde edilen verilere göre, deney grubundaki öğrencilerin ders sürecinde kavramın örneklerinden ve örnek olmayanlarından verimli bir şekilde yararlandıkları ve örneklerin öğrenmeyi kolaylaştırdığı söylenebilir. Buradan hareketle kavram öğretimi gerçekleştirilirken bir kavramın örnekleri kadar örnek olmayanlarının da sunulması önerilebilir.

3. Öğrencilerle yapılan mülakatlar sonucunda öğrencilerin Öge Gösterim Kuramı ile kavram öğretiminin diğer derslerde de kullanılmasına yönelik görüş bildirmeleri doğrultusunda, bu kuramın diğer derslerde kullanılmasına yönelik çalışmalar yapılabilir.

4. Araştırmada kullanılan öğretmen kılavuz kitabının öğretmene öğretim sürecinde destek olması sebebiyle, programda yer alan başka kavramlar ile kavram öğretimi stratejilerine yönelik öğretmenlerin faydalanabileceği öğretmen kılavuz kitapları hazırlanabilir.

5. Öğretmenler kavram öğretimi ile ilgili öğretim stratejileri ve modelleri hakkında bilgilendirilerek klasik ders işleme yöntemlerinin yerine daha kalıcı ve anlamlı öğrenmelerin hedeflendiği yeni yöntemler kullanmaya teşvik edilmelidir.

6. Öge Gösterim Kuramı teknoloji ile desteklenerek yeni öğretim materyalleri geliştirilebilir.

\begin{tabular}{r|l} 
Adres & Address \\
RumeliDE Dil ve Edebiyat Araşttrmaları Dergisi & RumeliDE Journal of Language and Literature Studies \\
Osmanağa Mahallesi, Mürver Çiçeği Sokak, No:14/8 & Osmanağa Mahallesi, Mürver Çiçeği Sokak, No:14/8 \\
Kadıköy - ISTANBUL / TÜRKIYE 34714 & Kadıköy - ISTANBUL / TURKEY 34714 \\
e-posta: editor@rumelide.com & e-mail: editor@rumelide.com, \\
phone: +90 505 7958124, +90 2167730616
\end{tabular}




\section{Kaynakça}

Adır Erben, T. (2011). Öge Gösterim Teorisi modeli ile bilgi değişim tekniğinin birlikte kullanılmasının matematik öğretimindeki etkililiğinin araştırılması (Yayınlanmamış yüksek lisans tezi). Frrat Üniversitesi, Fen Bilimleri Enstitüsü, Elazığ.

Akbaş, Y. (2008). Ortaöğretim 9. sını öğrencilerinin iklim konusundaki kavram yanılgılarmmn giderilmesinde kavramsal değişim yaklaşımının etkisi (Yayınlanmamış doktora tezi). Atatürk Üniversitesi, Sosyal Bilimler Enstitüsü, Erzurum.

Aktepe, V. vd. (2017). "Hayat bilgisi dersinde kavram öğretimi ve kavram öğretiminde kullanılabilecek teknikler üzerine kuramsal bir çalışma”. Uluslararası Sosyal Bilimler Eğitimi Dergisi, 3(1), 3350 .

Berg, B. L. ve Lune, H. (2015) Sosyal bilimlerde nitel araştırma yöntemleri (H. Aydın, Çev. Ed.). Ankara: Eğitim Yayınevi.

Büyüköztürk, Ş. vd. (2016). Bilimsel araştırma yöntemleri. Ankara: Pegema.

Creswell, Jw. (2017). Karma yöntem araştırmalarına giriş (M. Sözbilir, Çev. Ed.). Ankara: Pegema.

Creswell, Jw. and Plano-Clark, Vl. (2007).Designing and conducting: mixed methods research (Third Edition). Thousand Oaks, California: Sage Publication.

Dede, Y. (2003). Arcs Motivasyon Modeli ve Öge Gösterim Teorisi'ne (component display theory) dayalı yaklaşımın öğrencilerin değişken kavramın öğrenme düzeylerine ve motivasyonlarına etkisi (Yayınlanmamış doktora tezi). Gazi Üniversitesi, Eğitim Bilimleri Enstitüsü, Ankara.

Dede, Y. (2004). “Öge Gösterim Teorisi'nin bir uygulaması: Fonksiyon kavramının öğretimi”. Gazi Üniversitesi Kirşehir Ĕ̆itim Fakültesi Dergisi, 5 (2).

Eryllmaz, S. (2009). Web ortamında Öge Gösterim Kuramına göre tasarlanan kavram öğretiminin öğrencilerin akademik başarılarına, tutumlarına ve öğrenmenin kahcılı̆̆ına etkisi (Yayınlanmamış doktora tezi). Gazi Üniversitesi, Eğitim Bilimleri Enstitüsü, Ankara.

Eryılmaz, S. (2010). "Web ortamında Öge Gösterim Kuramına göre tasarlanan kavram öğretiminin uygulaması: Programlamada dizi kavramının öğretimi”. Ticaret ve Turizm Eğitim Fakültesi Dergisi, 2, 100-127.

Kaplan, Y. (1991). Enformasyon devrimi efsanesi. İstanbul: Rey

Karataş Coşkun, M. (1999). Ögeleri Belirleme Kuramına dayalı kavram öğretiminin akademik başar ve kahıchlğa etkisi (Yayınlanmamış doktora tezi). Çukurova Üniversitesi, Sosyal Bilimler Enstitüsü, Adana.

Karip, E. ve Köksal, K. (1996). "Etkili eğitim sistemlerinin geliştirilmesi”. Eğitim Yönetimi 2(2): 245247.

Kılıç, F. (2008). "Kavramların öğretiminde kavram analizi yönteminin akademik başarıya ve bilişsel esnekliğe etkisi”, Furat Üniversitesi Sosyal Bilimler Dergisi, 18/2, 223-238.

Kurt, E. (2018). Altıncı sinıf Türkçe dersi kavram öğretiminde animasyon ve hikâye kullanımınn başarıya etkisi (Yayınlanmamış doktora tezi). Karadeniz Teknik Üniversitesi, Eğitim Bilimleri Enstitüsü, Trabzon.

MEB (2006). İlköğretim Türkçe Dersi (6, 7, 8. Sinıflar) Öğretim Programı. Ankara.

Orhan K. ve H. G. (2018). "Merrill'in Bileşen Gösterim Kuramı'na genel bir bakış”. Turkish Studies. $13 / 3,495-524$.

Öğüt, A. (2003). Bilgi çă̆ında yönetim. Ankara: Nobel.

Özmen, H. (2005). "Kimya öğretiminde yanlış kavramlar: bir literatür araştırması". Türk Eğitim Bilimleri Dergisi. 3/1. 23-43.

Öztürk, P. T. (2011). İlköğretim 8. sınıf "canlılar ve enerji ilişkileri" ünitesinin kavram haritaları, yapılandırılmış grid ve tanılayıcı dallanmış ağaç teknikleri ile işlenmesinin öğrencilerin Fen

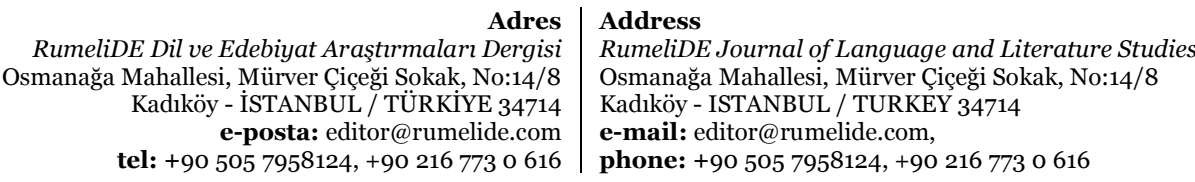


The effect of concept teaching based on component display theory on 7th grade students' achievements in Turkish lesson / T. Y. Cevher; S. Ungan (pp. 30-48)

ve Teknoloji dersine karşı tutumlarına etkisi (Yayınlanmamıs yüksek lisans tezi). Selçuk Üniversitesi, Eğitim Bilimleri Enstitüsü, Konya.

Sarıgül, Z. (2009). Çoktan seçmeli, yapılandırılmış grid ve kavram haritası tekniklerinin öğrenci başarısın ölçme açısından etkililiğinin incelenmesi ve öğrencilerin bu tekniklere ilişkin görüşleri. (Yayınlanmamış yüksek lisans tezi), Abant İzzet Baysal Üniversitesi Sosyal Bilimler Enstitüsü, Bolu.

Şimşek, A. (2017). Öğretim tasarımı. Ankara: Nobel.

Tan, E. (2008). İlköğretim 7. sinıf dil bilgisi öğretiminde zarflar konusuyla ilgili yapılandırmacı yaklaşıma göre hazırlanmış çalışma yapraklarının öğrenci başarısına etkisi (Yayınlanmamış yüksek lisans tezi). Atatürk UUniversitesi, Sosyal Bilimler Enstitüsü, Erzurum.

Von Hurst, E. M. (1984). The effectivenes of component display theory in the remedition of selfİnstructional materials for japanese learners, unpublished doctoral dissertation, California: University of Southern California.

Address

RumeliDE Journal of Language and Literature Studies

Osmanağa Mahallesi, Mürver Çiçeği Sokak, No:14/8

Kadıköy - ISTANBUL / TURKEY 34714

e-mail: editor@rumelide.com,

phone: +90 505 7958124, +90 2167730616 